Secondary publication on the edoc server of the Humboldt-Universität zu Berlin

https://doi.org/10.18452/21584

Originally published as:

Timothy Moss (2004) The governance of land use in river basins: prospects for overcoming problems of institutional interplay with the EU Water Framework Directive. Land Use Policy 21:1, 85-94.

https://doi.org/10.1016/j.landusepol.2003.10.001

This accepted manuscript version of the article stated above is licensed under a Creative Commons Attribution-NonCommercial-NoDerivatives 4.0 International License (CC BY-NCND 4.0) https://creativecommons.org/licenses/by-nc-nd/4.0/

\title{
The governance of land use in river basins: Prospects for overcoming problems of institutional interplay with the EU Water Framework Directive
}

Timothy Moss

\begin{abstract}
This paper examines the prospects for the interactive governance of water and land use following an initiative to institutionalise integrated river basin management. Taking an institutionalist perspective it first presents river basin management as a tool for overcoming problems of spatial fit and institutional interplay over water and land use. A case study of the implementation of the EU Water Framework Directive in Germany then explores opportunities and requirements for governance in future water management. On the basis of these findings the paper tests the validity of the thesis that the success of EU policy reform depends on the degree of 'fit' with existing institutional structures and practices.
\end{abstract}

\section{Keywords}

Governance, institutional change, river basin management, Water Framework Directive, land use 


\section{Introduction}

Water managers have long lamented their own powerlessness over forms of land use which have a detrimental impact on the quality of water bodies and availability of water resources. In spite of their warnings new urban developments are still being located on floodplains, intensive agricultural production continues to pollute groundwater resources and run-off from sealed or ploughed land is a growing source of environmental damage. The governance problem is partly territorial and partly administrative-political. On the one hand water and river authorities generally possess limited means of influencing uses of land and water both up-stream (longitudinally) and across the river catchment or basin (laterally). On the other hand they exercise little leverage over other policy fields which have a direct bearing on water quality and quantity issues, notably land-use planning, agriculture and forestry, hydro-electric power, navigation, nature conservation and economic development.

The European Union has recently created new opportunities for overcoming these problems in the form of the Water Framework Directive (WFD), adopted in December 2000 (EC 2000). The WFD institutionalises river basin management across the EU, requiring water management plans, programmes of measures and environmental quality objectives to be pursued on the scale of entire river basins. Within the broad range of policy objectives and instruments stipulated by the WFD, several have an explicit or implicit bearing on forms of land use relevant to maintaining and improving the quality of rivers, lakes and groundwater resources. By orienting water management around river basins the EU hopes to encourage a more holistic and territorially integrated approach to solving water-related problems. The new environmental quality objectives target not only point sources of pollution but also diffuse sources and - a major innovation for EU water policy - the geomorphological and biological status of rivers and lakes. Given past improvements in reducing point sources of pollution by building or upgrading sewage treatment systems, the emphasis of water protection measures in the Member States in future will be on minimising diffuse source pollution from agriculture and site contamination and restoring or rehabilitating rivers, river banks and floodplains to a more natural status. It is these objectives which will challenge many existing land-use practices, especially those determined by agricultural production, urban development and spatial planning. Achieving the objectives within the deadlines set by the WFD will require a degree of cooperation and negotiation with other policy fields very unfamiliar to water managers in many Member States. What forms this should take is left essentially to the individual Member States to decide, in accordance with the subsidiarity principle. Most experts are agreed, though, that meeting the letter and spirit of the WFD will require interactive governance not only between water managers but between them and those responsible for regulating land use.

This paper examines the prospects for forms of governance to address conflicts of interest between water and land use. It takes as a case study the current debate on implementing the WFD in Germany, where the challenge of institutional adaptation and innovation is particularly stark. Water management in Germany is currently not organised around river basins, bar a few organisations and instruments of minor significance. Regulatory, planning, 
policy-making and enforcement powers are divided between water authorities representing federal, state and municipal governments. Water management is characterised by a strong sectoral division of responsibility, a familiar feature of public administration in Germany. Furthermore, environmental management has relied heavily in the past on regulatory instruments, leaving water authorities inexperienced in participatory, cooperative forms of governance beyond formal consultation exercises. Against this institutional backdrop we explore here what new requirements and opportunities the WFD is creating for water management institutions to influence relevant land-use practices and, secondly, what forms of cross-sectoral governance relating to land-use issues are likely to emerge in Germany in response to the WFD. The term governance is used in this paper not in the sense of "governing without government" (Rhodes 1997) - i.e. through self-organised networks - but as a collective term for new modes of governing which extend beyond hierarchical forms of control. Distinctive characteristics of governance - in contrast to government - are the engagement of a wider range of actors, more intensive interaction between public and private actors and the greater importance of informal mechanisms of coordination (Koimann 1993; Pierre 1998).

These practical questions are embedded in theoretical considerations on institutional change and the emergence of new governance practices in multi-level systems of government. Specifically, the paper draws on, and contributes to, recent research into the implementation of EU environmental policy (Héritier et al. 1996; Hanf/Jansen 1998; Philip 1998; Jordan 2000; Knill/Lenschow 2000a, 2000b; Börzel 2000; Heinelt et al. 2001). The low level of EU policy implementation by Member States in the past has been widely attributed to technocratic forms of policy-making and the predominance of 'command-and-control' instruments. This assessment has, indeed, been instrumental behind a shift in the policy approach of the EU since the early 1990s. Recent EU directives have highlighted the importance of public participation, voluntary agreements, cross-sectoral integration, economic instruments, openness of information and flexibility to accommodate regional diversity. This is reflective of a generic shift in the process of governing from the imposition of control towards negotiated agreements. Research by Knill, Lenschow and Börzel has demonstrated, however, that EU Directives following this new approach have not proved easier to implement than those designed around the 'command-and-control' logic (Knill/Lenschow 2000a, 2000b; Börzel 2000). In countries with a policy style alien to negotiative and participatory governance - such as Germany and Spain - the new generation of EU Directives has posed severe problems of institutional adaptation. They conclude that effective implementation is dependent not on the policy type per se but on the degree of congruence 'fit' - with existing institutional structures and practices. The assumption for the implementation of the WFD in Germany is, therefore, that the chances of encouraging forms of governance conducive to resolving conflicts of interest between water and land use through negotiation are slim. This paper analyses the current debate on implementing the WFD in Germany with a view to testing this hypothesis and raising our understanding of the importance and persistence of institutional 'misfits'. 
The paper begins by briefly introducing river basin management as a tool designed to overcome problems of spatial fit and institutional interplay which are pertinent to conflicts of interest between water and land use. The following section outlines the requirements and opportunities for new forms of environmental governance created by the WFD relating to land use. The final analysis assesses the prospects for applying these governance forms in Germany on the basis of the ongoing debate over how to implement the WFD.

\section{River basin management: overcoming problems of spatial fit and institutional interplay}

Problems of spatial fit are familiar to political scientists, economists and geographers interested in determining optimal units of governance for various policy fields, in particular relating to the distribution of public goods (Olsen 1969; Ostrom 1990; Ostrom/Gardner/Walker 1994; Young 1999). The central argument is that lack of fit causes spatial externalities, benefiting free-riders and harming others beyond the spatial reach of the responsible institution. Creating better fit involves "structuring institutions in ways that maximise compatibility between institutional attributes and biogeophysical properties" (Young 1999: 48). Holzinger concludes similarly:

"disparities between functional space and political territory can only be removed by the reorganisation of political territories or by functional cooperation between the responsible jurisdictions" (2000:12, translation).

River basin management is a classic example of responding to problems of spatial fit. The attraction to water managers is to tackle what Mitchell and Pigram have termed "the political boundary problems that plague integrated resource management" (cited in Downs et al. 1991:300). By managing water resources according to the territorial unit of an ecosystem rather than political-administrative boundaries, river basin management is designed to address the interdependencies between, in particular, upstream and downstream effects, water quality and water quantity, and water and adjacent land-use resources (OECD 1989; Quarrie 1992; World Bank 1993; UN-ECE 1995). Experiences with the many practical applications of river basin management demonstrate, however, serious limitations to the logic of overcoming problems of spatial fit by reorganising water management around natural boundaries. The expectation that natural scientific knowledge could provide a template for the spatial organisation of water management has been only partially met. Since the late 1980s the literature on river basin management has, on the basis of extensive empirical evidence, begun to challenge the notion of creating perfect spatial fit which underlies a purist interpretation of river basin management (Downs et al. 1991; Mitchell 1990; Newson 1996, 1997). One of the principal criticisms is that the replacement of existing institutional units by institutions oriented around biophysical systems will inevitably create new boundary problems and fresh mismatches.

This raises the issue of institutional interplay. The basic idea is that "the effectiveness of specific institutions often depends not only on their own features but also on their interactions 
with other institutions" (Young 1999: 49). Institutional interplay refers to boundary problems of a different kind. The boundaries at stake here relate not to physical territories, but to political responsibilities and social spheres of influence. It is along these boundaries, where the jurisdictions and interests of organised actors overlap, that conflict between formal institutions most commonly arises (Mitchell 1990).

It is widely recognised that the effective protection of water resources cannot be achieved by institutions of water management alone. The quality and quantity of water resources are affected by a wide range of human activities - from agriculture to electricity generation, from recreation to industrial production - each framed by its own institutional arrangements. One of the principal problems is the "policy gap" between water management planning and landuse planning (Newson 1997:343). River basin management, to be effective, depends on coordinating mechanisms capable of bridging the gaps between the relevant institutions and organisations (OECD 1989). Referring to river basin management Mitchell argues that efforts to improve spatial fit depend for their success on parallel improvements to institutional interplay:

“... [T] here is never a perfect 'fit' among legitimisation instruments, functions and structures. As a result, use is made of various processes and mechanisms to overcome the problems which occur because of imperfect matches. It is often these processes and mechanisms, informal and formal, which facilitate co-ordination and integration" (Mitchell 1990: 214).

From this we can make two preliminary observations. Firstly, in the absence of an organisational blueprint for river basin management, the process of institutionalising river basin management, rather than the end-result, acquires particular significance. The solution ultimately chosen is framed by various - and often competing - logics of action upheld by the key actors, permitting some options while discounting others. Secondly, the task of winning broad support for a more integrated, holistic approach to water management demands extensive interaction between a wide range of parties. It requires complex negotiation and bargaining processes with other parties relevant to water resource management and the creation of new partnerships to solve basin-specific problems (Newson 1997). For most water authorities in Europe governance of this kind is unfamiliar territory indeed.

\section{The EU Water Framework Directive: requirements and opportunities for integrated approaches to water and land-use management}

To what extent does the WFD reflect this knowledge on the difficulties of institutionalising river basin management? Specifically, what importance is given to the interdependence of water management and land-use practices? The following section analyses the explicit and implicit requirements and opportunities for more interactive forms of governance over this issue under the WFD. 


\section{Ambitious policy framework for integrated water management}

The Water Framework Directive (2000/60/EC) sets water management in the EU on a new footing (EC 2000). It is designed to provide "a transparent, effective and coherent legislative framework" for European Community water policy (Preamble, Para.18). Within this framework surface waters and groundwater are to be protected using a common management approach and following common objectives, principles and basic measures across the EU (EC 2000). The core environmental objective is to prevent the deterioration of aquatic ecosystems and to restore polluted surface waters and groundwater to a "good" status in terms of ecological and chemical parameters, as well as water quantity, within a specified time frame from 15 to a maximum 27 years (Art.1). Additional objectives are to promote the sustainable use of water resources and to alleviate the effects of floods and droughts.

The key instrument of the WFD is river basin management. The WFD establishes the river basin as the unit for water management planning across the EU. Article 3 requires Member States to identify river basins within their territory and assign them to River Basin Districts. These River Basin Districts form the spatial unit for all environmental objectives and specified measures under the WFD, from river basin management plans and programmes of measures to monitoring activities. In addition, the WFD strengthens the so-called combined approach to pollution prevention, introduces economic analyses of water use, provides the general public with rights of involvement and information over river basin planning and establishes a detailed system of monitoring and reporting to the Commission. These innovations all have a substantial bearing on institutional aspects of water management.

\section{Requirements relating to land use}

Land-use issues are targeted by three innovative aspects of the WFD: river basin management, the combined approach to pollution prevention and the inclusion of hydromorphological parameter for the 'good' status of surface water. The first two instruments broaden the spatial dimensions of water management and, in doing so, create new obligations to consider the role of land use in causing water stress and in achieving the environmental objectives of the WFD. River basin management as institutionalised in the WFD requires water managers to look beyond the watercourses and take account of all human activities within each River Basin District which may have an impact on the availability and quality of water resources. The analysis of the characteristics of a River Basin District under Article 5 is to include a review of the impact of human activity on the status of surface water and groundwater across the whole river basin. The river basin management plan (Art.13) must provide a summary of these impacts of human activity relating to point source pollution, diffuse source pollution (including an overview of land use), pressures on the quantitative status of water including abstractions and other impacts according to Annex VII. The programme of measures (Art.11) sets out measures deemed necessary to meet the environmental objectives, seeking the most cost-efficient solutions across the river basin district.

The so-called combined approach refers to using both emission controls and environmental quality standards to prevent pollution (Art.10). Whereas emission controls based on Best Available Techniques target point sources of pollution, such as outlets from sewage treatment 
plants, environmental quality standards address in addition diffuse-source pollution determined by particular land-use forms (Holzwarth 2001:56). The principle pollutants from diffuse sources emanate from agricultural production (fertilizers, pesticides) and urban settlements (polluted run-off). It is generally recognised that, given the relative success of past EU Directives to improve wastewater treatment, the effect of the WFD will be to shift the emphasis of pollution prevention more towards addressing the forms of land use contributing to diffuse-source pollution (Interviews $2,3 \& 4$ ). This will mean in practice adopting countermeasures such as discouraging intensive agriculture on land close to lakes and rivers, using land-use planning to minimise urban run-off and retaining water in wetlands or polders (Quast et al. 2002). Measures of this kind aimed at creating a more 'natural' status for watercourses are further encouraged by the extension of environmental objectives in the WFD to include the geomorphology and fauna of rivers and lakes, as prescribed in Annex V. Meeting these targets will require - where necessary - river rehabilitation interventions ranging from the creation of buffer-strips along river banks to the restoration of floodplains. All these measures place new demands on land use, requiring far more intensive and effective interplay between water and land management than in the past.

\section{Requirements relating to the governance of land use}

The EU is not empowered to prescribe how its directives are implemented within the Member States. In accordance with the subsidiarity principle and in recognition of the diverse conditions and needs within the EU the WFD calls for "decisions to be taken as close as possible to the locations where water is affected or used" (Preamble, Para.13). Organisational and institutional implementation is the responsibility of the individual Member States. The WFD deliberately falls short of specifying the organisational structures for river basin management, requiring solely "appropriate administrative arrangements, including the identification of the appropriate competent authority" for each River Basin District (Art.3).

The WFD does, however, set down a number of procedural obligations which, in practice, are likely to have far-reaching consequences on the way integrated water management including interplay with land management - is organised. These relate to coordination across territorial boundaries, monitoring and reporting procedures, deadlines for implementation and forms of public consultation and information. Member States are required to coordinate their implementation activities - internally and with other EU states - across whole River Basin Districts (Stratenwerth 2002:325ff.). Coordination is obligatory not only when producing a national or international river basin management plan but also for more detailed programmes and management plans for sub-basins (Art.3 \& 13, cf. Interview 3). Specifications for involving the public are relatively modest and open to interpretation, prescribing a three-tier consultation procedure for the river basin plans, access to information and a general requirement to "encourage the active involvement of all interested parties in the implementation of th[e] Directive" (Art.14). More significant are likely to be the implementation obligations and control mechanisms incorporated in the WFD. Successful implementation will be measured ultimately in terms of whether or not the environmental objectives of the WFD have been met for each River Basin District within the designated timescale (cf. Leymann 2001:24, Stratenwerth 2002:326). A rigid timetable for monitoring 
progress, meeting the objectives and submitting reports and data to the Commission is designed to maximise implementation and avoiding circumvention by Member States (Art.15).

It is widely held that, in order to meet the wide-ranging objectives for good ecological status, intensive consultation and cooperation by the responsible water agencies will be essential. They will need coordinate with their colleagues across a whole river basin, to engage with the general public as specified under Art.14, but also to win the support of decision-makers in other policy fields relevant to implementing the WFD (Stratenwerth 2002:324, Interview 3). Water managers will not be able to meet the WFD's environmental objectives on their own. Conventional instruments of water management, such as abstraction licences, emission limit values and the designation of water protection zones will in many cases prove inadequate. Support will be needed from other policy fields relevant to water use, in particular those with a major influence over land use: agriculture, land-use planning and nature conservation. This support will not be gained lightly. Conflicts of interest over the use of land for agricultural production and urban settlements are likely to be high in those areas where measures are deemed necessary to meet the WFD's environmental objectives. If water managers are to adopt a more integrated approach to water protection they will need to cooperate to a far greater extent than in the past with organisations outside the sphere of water management. Institutional interplay and new forms of cross-sectoral governance, though not explicitly prescribed by the WFD, are therefore strongly implicit in its requirements.

\section{Policy style of the Water Framework Directive}

In terms of policy style the WFD represents, on the basis of this analysis, a hybrid type of EU directive. Following the categories of Knill et al. (see above) the WFD embodies some attributes of 'command-and-control' but it also lays great emphasis on cost-efficiency, processes of inter-agency negotiation and, to a lesser extent, public participation as well as allowing for regional diversity. Expressions of a 'command-and-control' approach include the detailed specifications on the content and procedure for the river basin management plans and programmes of measures, the strict monitoring and reporting obligations, the reduction or phasing-out of individual hazardous pollutants and the environmental quality objectives for surface water and groundwater. At the same time several key elements of the WFD require or encourage a new style of decision-making in and beyond the water community which is more open, more consultative and more participatory. The explicit expressions include the requirements for transparency in implementing the WFD and practicing river basin management, the involvement of the public, flexibility regarding the timescale for implementation and environmental standards for so-called "heavily modified water bodies", cost efficiency in pursuing environmental objectives and sensitivity to regional specifics natural, socio-economic and institutional. Implicitly the WFD will - if implemented fully require complex negotiations over future river basin management plans and programmes of measures conducted by a wide range of policy-makers and drawing on the inputs from interest groups and individual citizens. With this combination of the two policy styles - 'commandand-control' and the interactive, negotiative approach - the European Commission and others instrumental behind the WFD hope to maximise the prospects for effective implementation. 
To this end the Commission and national water directors are devising in close consultation a Common Implementation Strategy providing guidance on those elements of the WFD left for the Member States to finalise themselves.

\section{Promoting governance in Germany with the Water Framework Directive: a case of institutional misfit?}

How far the WFD will affect the governance of water and land use in practice will depend heavily on how it is interpreted and implemented in each Member State. The case of Germany is particularly illuminating because of the considerable degree of institutional adaptation that will be required there to implement the WFD. The following section analyses the current debate on the implementation of the WFD in Germany in order to identify the prospects for the emergence of consultative, negotiative forms of governance in river basin management, relating specifically to institutional interplay between water and land management. On the basis of these experiences it tests the validity of the thesis that the success of any policy reform depends on the degree of congruence with already existing institutional structures and practices.

\section{Anticipated misfit: the hypothesis}

Water management in Germany is traditionally organised around political-administrative units rather than river basins (on the following Kahlenborn/Kraemer 1999:127ff.). Legislative and executive responsibilities for water management are divided between federal, state and local authorities. This federal structure ensures a high degree of formal political legitimacy for water authorities at each administrative level. However, it has contributed to problems of spatial fit over managing water across river basins and problems of institutional diversity between the 16 states (Länder). Furthermore, public administration in Germany is characterised by strong functional division of responsibility which has in the past hampered institutional interplay. From the federal to the municipal level issues of water management, spatial planning, nature conservation and agriculture are administered by distinct organisational units unaccustomed to interacting beyond the scope of formalised planning procedures. Strong reliance on the rule of law is another distinctive feature of water management - and environmental policy generally - in Germany. Experience with nonformalised forms of interest group consultation or public participation is as a rule very limited.

Given this national administrative tradition of water management we might expect the implementation of the WFD - and in particular the adoption of new forms of governance - to be highly problematic in Germany. This follows from the argument of Knill and Lenschow that

"... effective implementation is basically dependent on the degree of institutional fit between existing institutional arrangements and the institutional implications emerging from European policies" (Knill/Lenschow 2000a:30). 
There would appear to be a clear case of institutional misfit between the state-centred, regulatory philosophy and administrative traditions of water management in Germany and the partnership-oriented, cross-sectoral aspects of the WFD. If this is the case the prospects for new forms of governance are slim. One might expect either considerable conflict over the introduction of more interactive processes or, alternatively, a minimalist response to implementation, whereby the policy-makers follow merely the letter, but not the spirit, of the WFD with regard to institutional changes.

\section{The response of the water managers: testing the hypothesis}

How, then, are the requirements and opportunities for interactive, negotiative forms of governance being pursued in Germany? In particular, how does the ongoing debate on implementing the WFD reflect the need for more effective forms of institutional interplay with land management? The first point to make is that water managers in Germany widely agree that implementing the WFD will mark a departure from traditional modes of water management (Holzwarth/Bosenius 2002:40). Referring to integrated river basin management, a leading official from the Federal Environment Ministry (BMU) remarks:

"This approach challenges the traditional management of watercourses in Germany, oriented strongly around administrative duties and political boundaries, and will require far more intensive cooperation and coordination between the various responsible authorities within a River Basin District" (Stratenwerth 2002:324, translation).

Water authorities accustomed to operating with regulatory instruments along vertical paths of the administrative hierarchy will in future need to cultivate more intensive forms of horizontal cooperation (Interview 4). This applies in the first instance to interaction between water authorities of different states and of Member States belonging to a single River Basin District. Beyond this, though, leading water managers acknowledge they will have to work much more closely with other authorities and interest groups (Interviews $2 \& 3$ ). As another leading water manager from the BMU comments:

"We will need to build up links to agriculture, land-use planning and nature conservation. Other policy fields will also need to be encouraged to participate in the discussions and take action themselves if the objectives of the Directive are to be implemented effectively and on schedule" (Holzwarth/Bosenius 2002:47, translation).

A representative of the Environment Ministry of Baden-Württemberg argues future cooperation "will of course go miles beyond the classical modes of administration we've had in the past" (Interview 2). Those affected by these plans - especially in agriculture, land-use planning, transport and nature conservation - are themselves exploring new modes of cooperation with the water authorities. The Academy for Spatial Research and Regional Planning (ARL) created a special working group to discuss the implications of the WFD for land-use issues and opportunities for spatial planning to assist in its implementation, submitting a report in late 2002 (ARL 2002).

Water managers in Germany intend to meet this challenge, however, with minimal change to existing institutional arrangements. It has been agreed by the state environment ministers that the WFD is to be implemented without any alteration to organisational structures or 
administrative responsibilities. State water authorities will retain their legislative and executive powers over water management in accordance with the federal structure of government in Germany. Cooperation within a River Basin District will be organised loosely in the form of cooperation agreements between state water authorities, rather than planning associations with independent executive powers. "So we are effectively retaining the administrative structure and laying a coordination structure along river basin boundaries across it" summarises one state official (Interview 4). This coordinating body for each River Basin District will possess no decision-making or executive powers but act primarily as a discussion forum for the water authorities, supported by a secretariat.

By choosing the path of minimal institutional change, state and federal water authorities in Germany have, wittingly or unwittingly, made themselves heavily dependent on nonformalised forms of cooperation and exchange if they are to implement the WFD effectively. Decisions made in the coordinating bodies in each River Basin District will not be legally binding on the participating states but will constitute mere recommendations. These recommendations will have to be pursued in each state by the state water authority, if necessary in consultation or cooperation with agencies from other relevant policy fields. This procedure may well require considerable negotiation, especially where conflicts of interest arise over physical interventions or over sources of funding. State water authorities will have to develop more intensive forms of interaction with public agencies, interest groups and other affected parties to compensate for the lack of any regulatory powers of a river basin authority.

This challenge is widely recognised amongst those closely involved in the implementation of the WFD. Yet it remains unclear which forms of governance lend themselves to meeting the challenge and which are the preferred options. The attention of the water authorities is currently focussed on implementing the most immediate requirements, notably reforming the federal and state water acts and conducting analyses of the status of water bodies. Issues that are less pressing or not explicitly prescribed in the WFD are receiving far less attention in most states. This applies to modes of cooperation with other policy fields - such as agriculture, spatial planning and nature conservation - but also to questions of how to identify cost-effective measures, how to distribute the burden of funding across states and how to tap funding resources from other policy fields to further the WFD's objectives.

The process of implementing the WFD, as described here, would appear to confirm the thesis of Knill and Lenschow that a misfit between the policy approach of an EU Directive and existing institutional arrangements in a Member State leads to inadequate implementation and/or conflict. The problem of spatial fit between the River Basin Districts and political territories of water management in Germany has been resolved in favour of the existing structures. There is a danger - as voiced by some environmentalists - that some state water authorities may be pursuing minimalist implementation, changing only what is explicitly required by the WFD and avoiding any additional innovations. It can also be observed how those elements of the WFD generally alien to the traditional practice of water management in Germany - such as cross-sectoral cooperation or public consultation - are generally not being given a high priority. 


\section{Openings for institutional change: the hypothesis challenged}

It would be wrong to conclude from these observations, however, that institutional misfits of this kind will necessarily prevent the development of more interactive forms of governance in German water management in the course of implementing the WFD. This would be to overemphasise the differences between the policy style of the WFD and existing institutions of water management in Germany and to overlook openings for institutional change in the German system. A closer look at the implementation debate reveals, namely, a number of points which suggest the degree of institutional misfit is not as great as it might seem from a broad-brush analysis of water management institutions.

Firstly, water managers in Germany largely welcome the institutionalisation of river basin management with the WFD. They approve of the WFD's integrated approach to water management, the greater attention to diffuse source pollution and the pressure for crossboundary cooperation across and along a whole river catchment. They see in the WFD an instrument that will strengthen their hand in preventing or remedying detrimental forms of land use (Leymann 2001; Interview 1).

Secondly, openness to new forms of governance relating to water and land use varies considerably between the 16 states. Whilst some state water authorities are clearly reluctant to pursue the unfamiliar path of partnership-building with other public agencies and interest groups, others are already practising a pro-active communication policy with the affected parties. For instance, the state of Baden-Württemberg has formed an advisory board for implementing the WFD comprising of representatives from ministries, business associations and NGOs beyond the field of water management (Interview 2). Information workshops with specific policy fields affected by the WFD are being conducted in Northrhine-Westphalia, Baden-Württemberg and Saxony. Bavaria has built up close cooperation with farming organisations to discuss the implications of the WFD (Interview 4). We can observe, therefore, a degree of regional diversity which relativises the notion of a monolithic national policy style implicit in recent research on institutional misfits.

Thirdly, implementing the WFD needs to be understood as an ongoing learning process. Many water managers are keen to avoid the mistakes of implementing earlier EU Directives when Germany was sanctioned for inadequate implementation or where state-centred implementation led to subsequent acceptance problems with those affected. For this reason most water authorities recognise the need for more consultative forms of governance but emphasise the importance of building on existing structures and practices rather than attempting a root-and-branch reform. Those water managers involved in devising the WFD draw on their positive experiences of consultation with their counterparts from other Member States and the European Commission before and after the Directive was passed. They point to the continuous dialogue on common ways of interpreting the WFD as a strength of the implementation process which they intend to pursue within their own states (Interview 2). This suggests that the prospects for partnership-building to resolve conflicts over water and land use are not as bleak as they appear at first sight. 
What this analysis indicates is that the process of implementing the WFD in Germany cannot be reduced to a 'battle of the systems' between two policy styles: 'command-and-control' versus 'network-oriented'. Such a simplification of the drivers and constraints of institutional change fails to capture the diversity and complexity of the implementation process. We have observed here how a distinctive national policy style can hide important regional differences, how established institutional procedures can adapt to pressures for change where the key actors perceive trade-offs and how unfamiliarity with certain governance forms does not automatically preclude acceptance. Within a single reform initiative - such as the WFD there can exist areas of low and high compatibility with existing institutions. The categorisation 'network-oriented' for a certain policy style can hide a wide variety of participatory, negotiative and consultative governance forms. There is also a time dynamic to institutional fit: the willingness to entertain institution change can alter as actors learn to appreciate its advantages. It is helpful to conceptualise processes of institutional adaptation, therefore, not as an issue of straight fit or misfit between two policy styles but as a process of framing, in which diverse - and often competing - logics of action shape each other to produce a particular set of institutional arrangements at a particular time in a particular place. From such a perspective we can understand better how the process of institutionalising integrated river basin management does not entail implementing an organisational blueprint but rather finding the most appropriate institutional structures and practices for a given context.

\section{Conclusion}

The new EU Water Framework Directive is creating new opportunities for overcoming problems of institutional interplay between water management and land-use policy and planning. How far the WFD will prove successful in encouraging consultative and participatory forms of governance between these two policy fields will depend to a large extent on the willingness of water authorities in each Member State to take a partnership approach to implementation. Recent research into the implementation of EU environmental policy suggests that this will prove difficult in those Member States which have traditionally relied on hierarchical, sectoral structures and regulatory instruments to achieve environmental objectives. Our case study of the current implementation of the WFD in one such Member State, Germany, demonstrates the value of the concept of institutional misfits as a way of explaining areas of conflict between existing institutions and new governance requirements of the WFD. Several aspects of minimal or delayed implementation can be accurately ascribed to the coexistence of contrasting policy styles. At the same time, our more in-depth study of implementation activities at the regional level has revealed some important deviations from this general picture. These relate in particular to water managers' approval of the principle tenets of the WFD, substantial regional diversity in the forms of cross-sectoral consultation practised and ongoing learning processes emerging from interaction between the affected parties. The case study suggests there are serious limitations to the use of a simple model of institutional misfit for identifying prospects for institutional change. Assessing the 
adaptability of existing institutions to pressures for change cannot be limited to determining straight fit or misfit. It entails, rather, identifying areas where fit or misfit exist, or might be anticipated, and exploring how the shifting context of an implementation process may contribute to increasing or reducing the scope for greater institutional fit. Understanding such processes in terms of framing and re-framing logics of action would appear to be a more fruitful way of analysing the prospects for the emergence and durability of certain forms of governance.

\section{Acknowledgements}

The research work for this paper was funded by the Institute for Regional Development and Structural Planning (IRS), Erkner (Germany) for the project "Institutional Change and Path Dependency" and by the European Commission in the context of the Framework 5 project "Floodplain Restoration and Biodiversity (FLOBAR) 2: Integrated natural science and socioeconomic approaches to catchment flow management" (contract no. EVK1-CT-1999-00031). The author would like to thank these organisations and the project teams for their support.

\section{References}

Akademie für Raumforschung und Landesplanung (ARL), 2002. Künftige Zusammenarbeit von Wasserwirtschaft und Raumplanung. Entwurf eines Abschlussberichtes des Ad-hoc-Arbeitskreises „EUWasserrahmenrichtlinie und Raumplanung“ der Akademie für Raumforschung und Landesplanung. Draft manuscript (unpublished).

Börzel, T. 2000. Improving compliance through domestic mobilisation? New instruments and the effectiveness of implementation in Spain. In: Knill, C. , Lenschow, A. (Eds.), Implementing EU environmental policy. New directions and old problems. Manchester University Press, Manchester/New York, pp.222-250.

Downs, P.W., Gregory, K.J., Brookes, A., 1991. How Integrated is River Basin Management? Environmental Management 15(3), 299-309.

European Community (EC), 2000. Directive 2000/60/EC of the European Parliament and of the Council of 23 October 2000 establishing a framework for Community action in the field of water policy. In: Official Journal of the European Communities, 22.12.2000, L 327/1-72.

Hanf, K., Jansen, A., 1998. Environmental policy - the outcome of strategic action and institutional characteristics. In: Hanf, K., Jansen, A. (Eds.), Governance and Environment in Western Europe. Longman, Harlow, pp.1-16.

Heinelt, H., Malek, T., Smith, R., Töller, A.E. (Eds.) 2001. European Union Environment Policy and New Forms of Governance. Ashgate, Aldershot.

Héritier, A., Knill, C., Mingers, S. 1996. Ringing the Changes in Europe. Regulatory Competition and Redefinition of the State. Britain, France, Germany. Walter de Gruyter, Berlin.

Holzinger, K. 2000. Optimale Regulierungseinheiten für Europa. Flexible Kooperation territorialer und funktionaler Jurisdiktionen. Unpublished paper presented to $21^{\text {st }}$ Scientific Congress of the DVPW, 1-5 October in Halle. 
Holzwarth, F. 2001. Wasser im 21. Jahrhundert - Handlungsfelder aus der Sicht der Bundesrepublik. In: Brickwedde, F. (Ed.), Wasser im 21. Jahrhundert - Perspektiven, Handlungsfelder, Strategien. 6. Internationale Sommerakademie St.Marienthal, Bramsche, pp.51-62.

Holzwarth, F., Bosenius, U. 2002: Die Wasserrahmenrichtlinie im System des europäischen und deutschen Gewässerschutzes. In: v. Keitz, S., Schmalholz, M. (Eds.), Handbuch der EU-Wasserrahmenrichtlinie. Inhalte, Neuerungen und Anregungen für die nationale Umsetzung. Erich Schmidt Verlag, Berlin, pp.2748.

Jordan, A., 2000. The politics of multilevel environmental governance: subsidiarity and environmental policy in the European Union. Environment and Planning A 32, 1307-1324.

Kahlenborn, W., Kraemer, R.A. 1999. Nachhaltige Wasserwirtschaft in Deutschland. Springer-Verlag, Berlin/Heidelberg.

Knill, C., Lenschow, A. 2000a. On deficient implementation and deficient theories: the need for an institutionalist perspective in implementation research. In: Knill, C. , Lenschow, A. (Eds.), Implementing EU environmental policy. New directions and old problems. Manchester University Press, Manchester/New York, pp.9-35.

Knill, C., Lenschow, A. 2000b. Do new brooms really sweep cleaner? Implementation of new instruments in EU environmental policy. In: Knill, C. , Lenschow, A. (Eds.), Implementing EU environmental policy. New directions and old problems. Manchester University Press, Manchester/New York, pp.251-286.

Koimann, J. (1993): Modern Governance. New Government-Society Interactions. London.

Leymann, G. 2001. Die Bedeutung der Wasserrahmenrichtlinie für die Bundesländer. In: Brickwedde, F. (Ed.), Wasser im 21. Jahrhundert - Perspektiven, Handlungsfelder, Strategien. 6. Internationale Sommerakademie St.Marienthal, Bramsche, pp.23-25.

Lipschutz, R.D., 1999. Bioregionalism, civil society and global environmental governance. In: McGinnis, M.V. (Ed.), Bioregionalism. Routledge, London/New York, pp.101-120.

Mitchell, B., 1990. Integrated water management. In: Mitchell, B. (Ed.), Integrated Water Management: International Experiences and Perspectives. Belhaven Press, London/New York, pp.1-21.

Newson, M., 1996. Land, Water and Development: Key themes driving international policy on catchment management. In: Cresser, M., Pugh, K. (Eds.), Multiple Land Use and Catchment Management. International Conference, 11-13 September 1996. The Macauley Land Use Research Institute, Aberdeen, pp.11-21.

Newson, M., 1997. Land, Water and Development. Sustainable management of river basin systems. $2^{\text {nd }}$ ed. Routledge, London/New York.

Olson, M., 1969. The Principle of "Fiscal Equivalence": The Division of Responsibilities among Different Levels of Government. The American Economic Review 59, 479-487.

Organisation for Economic Co-operation and Development (OECD), 1989. Water Resource Management. Integrated Policies. OECD, Paris.

Ostrom, E., 1990. Governing the Commons. The evolution of institutions for collective action. Cambridge University Press, Cambridge.

Ostrom, E., Gardner, R., Walker, J., 1994. Rules, Games, and Common-Pool Resources. University of Michigan Press, Ann Arbor.

Philip, A.B., 1998. The European Union: Environmental policy and the prospects for sustainable development. In: Hanf, K., Jansen, A. (Eds.): Governance and Environment in Western Europe. Longman, Harlow, pp.253-276.

Pierre, J. (1999): Models of Urban Governance. The Institutional Dimension of Urban Politics. Urban Affairs Review 34, 372-396.

Quarrie, J. (Ed.), 1992. Earth Summit '92: The United Nations Conference on Environment and Development. Regency Press, London. 
Quast, J., Steidl, J., Müller, K., Wiggering, H. 2002: Minderung diffusere Stoffeinträge. In: v. Keitz, S., Schmalholz, M. (Eds.), Handbuch der EU-Wasserrahmenrichtlinie. Inhalte, Neuerungen und Anregungen für die nationale Umsetzung. Erich Schmidt Verlag, Berlin, pp.177-219.

Rhodes, R.A.W. (1997): Understanding Governance. Policy Networks, Governance, Reflexivity and Accountability. Buckingham.

Stratenwerth, T. 2002. Die Bewirtschaftung nationaler und internationaler Flussgebiete. In: v. Keitz, S., Schmalholz, M. (Eds.), Handbuch der EU-Wasserrahmenrichtlinie. Inhalte, Neuerungen und Anregungen für die nationale Umsetzung. Erich Schmidt Verlag, Berlin, pp.323-342.

United Nations Economic Commission for Europe (UN-ECE), 1995. Protection and Sustainable Use of Waters. Recommendations to ECE Governments. Water Series No.2. United Nations, New York/Geneva.

World Bank, 1993. Water Resources Management. A World Bank Policy Paper. The World Bank, Washington, D.C..

Young, O., 1999. Institutional Dimensions of Global Environmental Change. Science Plan. IHDP Report No.9, IHDP, Bonn.

\section{Interviews}

With representatives from:

1. Federal Ministry for the Environment, Nature Conservation and Nuclear Safety, Water Protection Unit, 23.04.2002

2. Ministry for the Environment and Transport of Baden-Württemberg, Water Department, 24.04.2002

3. State Ministry for Agriculture and the Environment of Bavaria, Water Department, 02.05.2002

4. State Ministry for Agriculture and the Environment of Bavaria, Water Department, 02.05.2002 